Tersedia online di: http://ejournal-balitbang.kkp.go.id/index.php/ma

\title{
BUDIDAYA UDANG VANAME DENGAN PADAT PENEBARAN TINGGI
}

\author{
Rachman Syah\#, Makmur, dan Mat Fahrur \\ Balai Riset Perikanan Budidaya Air Payau dan Penyuluhan Perikanan \\ (Naskah diterima: 5 Juni 2017; Revisi final: 19 Juni 2017; Disetujui publikasi: 19 Juni 2017)
}

\begin{abstract}
ABSTRAK
Upaya meningkatkan produktivitas lahan tambak dapat dilakukan dengan meningkatkan padat penebaran disertai dengan pemberian akuinput yang prima serta dukungan teknologi yang memadai. Tiga padat penebaran yaitu 750; 1.000; dan $1.250 \mathrm{ekor} / \mathrm{m}^{2}$, diaplikasikan pada tambak dengan luasan $1.000 \mathrm{~m}^{2}$ dengan kedalaman air 1,8 $\mathrm{m}$ dilengkapi dengan sistem aerasi berupa kincir dan root blower, pompa submersible, automatic feeder, central drain dan collector drain serta Instalasi Pengolah Air Limbah (IPAL). Kapasitas sistem aerasi adalah $500 \mathrm{~kg}$ biomassa udang/HP. Udang dipelihara selama 105 hari. Hasil penelitian menunjukkan bahwa padat penebaran yang diaplikasikan menghasilkan bobot akhir udang yang relatif sama berkisar $15,48-16,30(15,78 \pm 0,45)$ g/ekor dengan nilai pertumbuhan harian 0,16-0,18 $(0,17 \pm 0,01)$ g/hari. Produksi yang diperoleh adalah 7.862; 10.699; dan $12.163 \mathrm{~kg} /$ petak, masing-masing pada padat penebaran 750; 1.000 dan $1.250 \mathrm{ekor} / \mathrm{m}^{2}$. Nilai rasio konversi pakan 1,4; 1,36; 1,55 dan kebutuhan listrik 3,2; 2,5; 2,4 kw/ $\mathrm{kg}$ udang serta kebutuhan air 2,24; 1,66;1,60 $\mathrm{m}^{3} / \mathrm{kg}$ udang. Biaya produksi udang terendah adalah Rp. $30.526 / \mathrm{kg}$ udang pada padat penebaran $1.000 \mathrm{ekor} / \mathrm{m}^{2}$ dengan laba operasional sebesar Rp. 630.687.094/ th. Padat penebaran $1.000 \mathrm{ekor} / \mathrm{m}^{2}$ menghasilkan kinerja lebih baik sehingga disarankan menjadi acuan padat penebaran untuk budidaya udang vaname superintensif. Teknologi ini memiliki potensi dampak terhadap lingkungan perairan, sehingga perlu dilengkapi sarana Instalasi Pengolah Air Limbah (IPAL) untuk pengolah air buangan tambak.
\end{abstract}

\section{KATA KUNCI: padat penebaran; udang vaname; superintensif}

ABSTRACT: The Litopenaeus vanamei aquaculture under high stocking density. By Rachman Syah, Makmur, and Mat Fahrur

In order to increase of brackishwater pond's productivity, an effort can be reached through high stocking density of shrimp accompanied by application of high quality inputs and supported by an appropriate technology. Three different stocking densities, were applied i.e., $750 ; 1,000 ;$ and $1,250 \mathrm{ind} / \mathrm{m}^{2}$. The shrimp were reared for 105 days in three ponds with sizing of $1,000 \mathrm{~m}^{2}$ each and the water depth of $1.8 \mathrm{~m}$ facilitated with aeration systems consisted of paddlewheels, root blower, submersible water pump, automatic feeder, central drainage, collector drainage and waste water treatment plan. The capacity aeration systems was $500 \mathrm{~kg}$ of shrimp biomass/HP. The results showed that all stocking densities produced the similar final body weight of shrimp which ranged between 15.48 to $16.30(15.78 \pm 0.45)$ $\mathrm{g} /$ shrimp with daily growth rates were $0.16-0.18(0.17 \pm 0.01) \mathrm{g} /$ day. The total harvested shrimps from each stocking density were 7,$862 ; 10,699,12,163 \mathrm{~kg} /$ pond, respectively. The feed conversion ratio was 1.4, 1.36, and 1.55, whereas consumed electricities were $3.2,2.5$, and $2.4 \mathrm{kw} / \mathrm{kg}$ shrimp and water demands were 2.24, 1.66, and 1.60 $\mathrm{m}^{3} / \mathrm{kg}$ harvested shrimp. The lowest production cost was IDR 30,526/kg harvested shrimp which was spent for stocking density of $1,000 \mathrm{ind} / \mathrm{m}^{2}$, whereas the annual profit was IDR $630,687,094$. The stocking density of $1,000 \mathrm{ind} / \mathrm{m}^{2}$ showed high performances, and then eventually is recommended for the $L$. vannamei super-intensiveaquaculture. This technology is potential in affecting the adjacent environment, however the impacts might be minimized through the application of deploying wastewater treatment plan.

\section{KEYWORDS: stocking densities; Litopenaeus vannamei; super-intensive}

\footnotetext{
\# Korespondensi: Balai Riset Perikanan Budidaya Air Payau dan Penyuluhan Perikanan. Jl. Makmur Dg. Sitakka No. 129, Maros 90512, Sulawesi Selatan, Indonesia.

Tel.: + (0411) 371544

E-mail: rachman222000@yahoo.com
} 


\section{PENDAHULUAN}

Udang vaname masih menjadi tumpuan yang strategis bagi upaya pencapaian target produksi udang nasional. Teknologi budidaya udang vaname superintensif menjadi orientasi sistem budidaya masa depan dengan konsep low volume high density. Teknologi budidaya ini memiliki ciri luasan petak tambak $1.000 \mathrm{~m}^{2}$ sehingga mudah dikontrol; kedalaman air > 1,8 m; padat penebaran tinggi; produktivitas tinggi; beban limbah minimal; dilengkapi dengan tandon air bersih dan petak pengolah buangan air hasil samping selama proses budidaya. Lingkungan dan hamparan budidaya yang terkontrol dengan manajemen limbah budidaya yang baik diharapkan menjadi suatu sistem budidaya udang vaname yang produktif, menguntungkan, dan berkelanjutan.

Budidaya udang vaname dengan padat penebaran tinggi telah dilakukan menggunakan sistem raceway $\left(271 \mathrm{~m}^{2}\right)$ dan pada padat penebaran $300-810 \mathrm{ekor} / \mathrm{m}^{2}$ (Venero et al., 2009); 658-1602 ekor $/ \mathrm{m}^{3}$ (Lawrence, 2010); sistem raceway $40 \mathrm{~m}^{3}$ pada padat penebaran $530 \mathrm{ekor} / \mathrm{m}^{3}$ (Samocha et al., 2010b); sistem raceway 40-100 $\mathrm{m}^{3}$ pada padat penebaran 390-500 ekor $/ \mathrm{m}^{3}$ (Samocha et al., 2012); sistem bioflok pada raceway $100 \mathrm{~m}^{3}$ dengan padat penebaran 500 ekor $/ \mathrm{m}^{3}$ (Samocha et al., 2013a). Data yang ada menunjukkan bahwa budidaya udang vaname dengan padat penebaran tinggi dilakukan di wadah kecil $<100 \mathrm{~m}^{3}$ dengan sistem indoor. Sejak tahun 2011, di Indonesia dikembangkan budidaya udang vaname superintensif pada tambak $1.000 \mathrm{~m}^{2}$ dengan padat penebaran 312-1.000 ekor $/ \mathrm{m}^{2}$ (Atjo, 2013).

Padat penebaran tinggi yang diaplikasikan dalam sistem budidaya superintensif diharapkan akan diikuti dengan peningkatan produksi, namun ada batas tertentu di mana daya dukung tambak tidak lagi mampu menopang kehidupan udang dalam jumlah biomassa tertentu. Oleh karena itu, diperlukan penentuan padat penebaran optimal agar diperoleh biaya produksi yang minimal dengan tingkat keuntungan yang maksimal sehingga produk udang yang dihasilkan berdaya saing tinggi.

Padat penebaran merupakan penentu tingkat teknologi dan akuainput yang dibutuhkan dalam sistem budidaya. Alokasi padat penebaran di atas daya dukung lingkungan dapat mempengaruhi sistem budidaya yang menciri pada gagal panen akibat beban limbah yang berlebih di atas kapasitas asimilasi lingkungan perairan. Penelitian ini bertujuan untuk mendapatkan data dan informasi kinerja budidaya udang vaname superintensif pada padat penebaran yang berbeda sebagai acuan untuk menentukan padat penebaran optimal udang vaname pada teknologi superintensif. Diharapkan aplikasi padat penebaran yang optimal akan berdampak pada produktivitas dan keuntungan yang maksimal dengan sistem produksi yang berkelanjutan

\section{BAHAN DAN METODE}

Penelitian dilakukan dari bulan Januari-Agustus 2014, di Instalasi Tambak Percobaan Balai Penelitian dan Pengembangan Budidaya Air Payau yang berlokasi di Desa Punaga, Kecamatan Mangarabombang, Kabupaten Takalar. Tiga petak tambak berukuran 1.000 $\mathrm{m}^{2}$ yang dilengkapi dengan sistem aerasi berupa kincir dan blower dan satu petak tambak berukuran 1.000 $\mathrm{m}^{2}$ digunakan sebagai tandon bantu. Jumlah aerasi ditentukan berdasarkan hasil penelitian Hopkins et al. (1991), bahwa aerasi dengan kekuatan 1 HP dapat memfasilitasi pemberian pakan sebanyak $16 \mathrm{~kg}$ per hari dengan mempertahankan kadar oksigen hingga 3 $\mathrm{mg} / \mathrm{L}$ dengan target biomassa udang yang dipanen sebanyak 550 - $600 \mathrm{~kg}$ per HP. Jumlah kapasitas aerasi (HP) terpasang di tambak, dengan demikian ditentukan berdasarkan produksi biomassa udang sebagai respon padat penebaran yang diaplikasikan dibagi dengan kapasitas dari aerasi tersebut untuk menopang kehidupan udang secara optimal.

Pengisian air tambak setinggi $100 \mathrm{~cm}$ diikuti dengan aplikasi kapur dolomit 20 ppm, aplikasi klorin $40 \mathrm{ppm}$, pemupukan dengan urea $20 \mathrm{~kg} /$ petak dan SP-36 sebanyak $10 \mathrm{~kg} /$ petak, plankton dibiarkan tumbuh selama dua minggu, serta probiotik diaplikasikan dengan dosis $50 \mathrm{~g} /$ petak. Penebaran benur dilakukan setelah seminggu aplikasi probiotik, yaitu pada tanggal 15 M aret 2014.

Benur udang vaname PL-10 diperoleh dari unit perbenihan di Anyer-Jawa Barat dengan sertifikat bebas WSSV, Taura, dan IMNV. Adaptasi terhadap suhu dan salinitas perairan dilakukan sebelum benur ditebar di tambak. Padat penebaran yang diaplikasikan adalah 750 ekor $/ \mathrm{m}^{2}$ (petak A), 1.000 ekor $/ \mathrm{m}^{2}$ (petak B), dan 1.250 ekor $/ \mathrm{m}^{2}$ (petak $\mathrm{C}$ ). Penentuan padat penebaran merupakan pengembangan dari penelitian sebelumnya yaitu 500 dan 600 ekor $/ \mathrm{m}^{2}$ (Tahe et al., 2014).

Pakan dengan kadar protein 40-36\%diberikan secara manual sampai pada hari ke-60, selanjutnya pakan diberikan dengan alat bantu automatic feeder dimulai pada Day Old Culture (DOC)-61 sampai panen. Dosis pakan disesuaikan dengan perkembangan pertumbuhan udang dan kondisi udang di tambak. 
Pemasangan anco sebanyak 4 buah di setiap petak tambak ditujukan sebagai alat bantu untuk memantau respon udang terhadap pakan yang diberikan.

Selama pemeliharaan dilakukan pengelolaan air meliputi pembuangan lumpur dari central drain dan pengisian air tambak sesuai penyusutan air tambak. Probiotik komersial diaplikasikan sesuai standar operasional prosedur (SOP) dan dosisnya disesuaikan dengan perkembangan bobot udang dan kondisi populasi total bakteri.

Peubah yang diamati selama pemeliharaan meliputi pertumbuhan udang yang diukur setiap lima hari dengan cara menimbang udang menggunakan timbangan elektronik yang mempunyai ketelitian $0,01 \mathrm{~g}$. Sebanyak 100 ekor udang yang diperoleh dari anco dan atau jala digunakan sebagai sampel. Data penimbangan bobot udang secara perio dik digunakan untuk menghitung kebutuhan pakan harian.

Parameter kualitas air meliputi suhu, salinitas, oksigen terlarut, dan $\mathrm{pH}$ dipantau setiap hari di tambak menggunakan DO meter model YSI650, sementara TSS, BOT, total ammonium nitrogen (TAN), nitrit, nitrat, fosfat diukur setiap dua minggu di laboratorium.

Panen dilakukan secara parsial sebanyak 20-30\% biomassa udang pada pemeliharaan hari ke-70 dan 90, sedangkan panen total dilakukan pada hari ke 105. Data produksi, sintasan, rasio konversi pakan (RKP), kebutuhan air, kebutuhan listrik, dan keragaman udang dihitung diakhir penelitian. Ukuran udang saat panen ditentukan berdasarkan sampling sebanyak $20 \mathrm{~kg}$, kemudian dihitung jumlah individu sebagai pembaginya.

Data yang diperoleh dianalisis secara deskriptif untuk mengetahui pengaruh padat penebaran terhadap respon biologi udang dan karakteristik lingkungan perairan tambak. Analisis biaya dilakukan untuk mengetahui tingkat keuntungan dari kegiatan budidaya udang vaname superintensif.

\section{HASIL DAN BAHASAN}

Hasil penimbangan bobot udang vaname selama pemeliharaan menunjukkan nilai bobot yang relatif sama untuk ketiga padat penebaran. Pada DOC-70, bobot udang 9,42 $\pm 1,82$ g/ekor; DOC-90 $(13,85 \pm 2,24)$ g/ekor; dan DOC-105 (16,79 $\pm 2,57)$ g/ekor. Ada kecenderungan variasi ukuran bobot udang semakin mengecil sehingga mengindikasikan adanya keseragaman ukuran udang saat panen. Pertumbuhan udang vaname pada padat penebaran 750-1.250 ekor/ $\mathrm{m}^{2}$ dinilai masih dalam batas pertumbuhan normal.
Pertambahan bobot harian cukup berfluktuasi. Pada DOC-31-60, pertambahan bobot harian udang pada padat penebaran $750,1.000$, dan $1.250 \mathrm{ekor} / \mathrm{m}^{2}$, berturut-turut adalah $0,11-0,35(0,18 \pm 0,08) ; 0,10-0,36$ $(0,18 \pm 0,09)$; dan $0,11-0,31(0,18 \pm 0,07) \mathrm{g} /$ hari, sementara pada DOC-61-105, pertambahan bobot harian masing-masing perlakuan adalah 0,05-0,28 $(0,19 \pm 0,09) ; 0,12-0,33(0,22 \pm 0,06) ;$ dan $0,10-0,28$ $(0,22 \pm 0,07) \mathrm{g} /$ hari. Beberapa hasil penelitian menyebutkan bahwa pertumbuhan udang vaname dipengaruhi oleh padat penebaran dengan aplikasi penebaran 50-61 ekor $/ \mathrm{m}^{2}$ (Balakrishnan et al., 2011), 40-80 ekor $/ \mathrm{m}^{2}$ (Krishna et al., 2015), 150-450 ekor $/ \mathrm{m}^{2}$ (Krummenauer et al., 2011), dan 200-400 ekor $/ \mathrm{m}^{2}$ (Otoshi et al., 2007). Namun pada penelitian ini, padat penebaran antara 750-1.250 ekor/m² justru menghasilkan pertumbuhan udang yang relatif sama. Hal yang sama terjadi pada padat penebaran 500 dan $600 \mathrm{ekor} / \mathrm{m}^{2}$ yang menghasilkan pertambahan bobot harian 0,14 g/hari (Tahe et al., 2014); 0,18 0,01 g/hari pada padat penebaran $530 \mathrm{ekor} / \mathrm{m}^{3}$ (Samocha et al., 2010a); 0,19 $\pm 0,01 \mathrm{~g} /$ hari pada padat penebaran 450 ekor $/ \mathrm{m}^{3} ; 0,26 \pm 0,01 \mathrm{~g} /$ hari pada padat penebaran 500 ekor $/ \mathrm{m}^{3}$ dan 0,21 $\pm 0,01 \mathrm{~g} /$ hari pada penebaran 390 ekor $/ \mathrm{m}^{3}$ (Samocha et al., 2013b); 0,22 $\pm 0,07$ g/hari $\left(1.111\right.$ ekor $\left./ \mathrm{m}^{3}\right)$; dan $0,19 \pm 0,03 \mathrm{~g} /$ hari pada padat penebaran $1.602 \mathrm{ekor} / \mathrm{m}^{3}$ (Lawrence, 2010). Dari data yang ada menunjukkan bahwa udang vaname sangat toleran terhadap padat penebaran tinggi dan tidak berpengaruh pada pertumbuhan udang. Diduga kemampuan udang vaname untuk memanfaatkan seluruh kolom air dan didukung oleh kualitas air yang prima serta ketersediaan nutrisi yang bagus, memberikan respons pertumbuhan udang yang relatif sama dan tidak dipengaruhi oleh padat penebaran yang diaplikasikan. Wasielesky et al. (2013), melaporkan bahwa udang vaname yang dibantut selama 35 hari dengan padat penebaran 1.500-6.000 ekor $/ \mathrm{m}^{2}$, memberikan respon pertumbuhan kompensasi yang tidak berbeda nyata setelah dipelihara dengan padat penebaran 300 ekor $/ \mathrm{m}^{2}$ selama 20 hari.

Padat penebaran 750 ekor $/ \mathrm{m}^{2}$ menghasilkan sintasan tertinggi $87,3 \%$ disusul padat penebaran 1.000 dan $1.250 \mathrm{ekor} / \mathrm{m}^{2}$, masing-masing $82,9 \%$ dan $79,1 \%$ (Tabel 1). Semakin tinggi padat penebaran, semakin rendah sintasan udang vaname. Hasil penelitian Krummenauer et al. (2011), melaporkan padat penebaran $150 \mathrm{ekor} / \mathrm{m}^{2}$ menghasilkan sintasan $92,0 \%$ kemudian diikuti padat penebaran 300 dan 450 ekor/ $\mathrm{m}^{2}$, masing-masing $81,2 \%$ dan $75,0 \%$ Meningkatnya padat penebaran akan menurunkan sintasan udang vaname juga dilaporkan oleh Krishna et al. (2015) dan 
Venero et al. (2009). Sebaliknya Tahe et al. (2014) mendapat sintasan $85,6 \%$ dan $92,4 \%$ pada padat penebaran 500 dan $600 \mathrm{ekor} / \mathrm{m}^{2}$. Sementara Samocha et al. (2013b) melaporkan sintasan udang vaname cukup bervariasi masing-masing 83,0\%(390 ekor $\left./ \mathrm{m}^{3}\right)$; 95,5\%(450 ekor $\left./ \mathrm{m}^{3}\right) ; 81,6 \%\left(500 \mathrm{ekor} / \mathrm{m}^{3}\right) ;$ dan $82,3 \%$ $\left(530 \mathrm{ekor} / \mathrm{m}^{3}\right)$. Pada padat penebaran $1.111 \mathrm{ekor} / \mathrm{m}^{3}$ dan 1.602 ekor $/ \mathrm{m}^{3}$ menghasilkan sintasan masing-

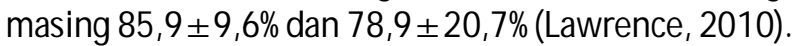
Hal ini menjelaskan bahwa kemungkinan terdapat padat penebaran optimal yang akan menghasilkan respons maksimal terhadap sintasan udang vaname karena terkait dengan kompetisi pemanfaatan ruang, peluang kontak antar individu terkait kanibalisme dan distribusi patogen, serta persaingan mendapatkan pakan.Tingginya sintasan yang diperoleh dalam penelitian ini menunjukkan bahwa lingkungan air tambak masih kondusif menopang kehidupan udang sampai padat penebaran $1.250 \mathrm{ekor} / \mathrm{m}^{2}$.

Rasio konversi pakan (RKP) mengindikasikan tingkat kemampuan udang dalam memanfaatkan ransum pakan. RKP pada petak $C$ sebesar 1,55 lebih tinggi dibandingkan pada petak $A$ dan $B$, masingmasing 1,40 dan 1,36 (Tabel 1). Tingginya RKP pada petak $C$ dapat disebabkan oleh estimasi populasi atau biomassa udang kurang akurat sehingga mengakibatkan pemberian jumlah pakan bisa berlebih, terutama pada saat udang ganti kulit. Pengamatan pakan melalui anco masih menjadi alternatif dalam manajemen pemberian pakan. Penelitian sebelumnya dengan padat penebaran 500 dan 600 ekor $/ \mathrm{m}^{2}$ menghasilkan RKP masing-masing 1,59 dan 1,39 (Tahe et al., 2014); 1,53-1,60 pada padat penebaran 450 ekor/ $\mathrm{m}^{3}$ dan 1,21-1,40 pada padat penebaran $530 \mathrm{ekor} / \mathrm{m}^{3}$ (Samocha et al., 2010a); 1,77 (390 ekor/m³),1,48 (500 ekor $/ \mathrm{m}^{3}$ ) (Samocha et al., 2013b).

Budidaya udang vaname superintensif memberikan konsekuensi pada tingginya bobot biomassa udang di tambak. Pengendalian terhadap bobot biomassa populasi udang agar tetap dalam batas daya dukung lingkungan tambak menjadi suatu keharusan dalam manajemen tambak superintensif, melalui panen secara parsial. Tujuan panen parsial adalah (1) mengendalikan biomassa udang tidak melebihi batas daya dukung lingkungan tambak, (2) memberikan peluang udang yang tertinggal tumbuh secara lebih baik akibat adanya pengurangan kondisi berjejal dan menurunnya beban limbah sehingga udang hidup lebih nyaman. Panen parsial telah dilakukan oleh Taw et al. (2006) di tambak intensif udang vaname dan Moss et al. (2005) pada budidaya udang vaname superintensif dengan sistem resirkulasi. Panen parsial yang dikelola dengan baik dapat meningkatkan produktivitas dan keuntungan pada budidaya udang dengan kepadatan tinggi (Yu \& Leung, 2006). Sementara piranti sistem pendukung pengambilan keputusan untuk panen parsial pada kegiatan budidaya telah dikembangkan oleh Yu et al. (2010). Moss et al. (2005) mengatakan bahwa panen parsial lebih menguntungkan dibandingkan panen tunggal.

Tabel 1. Kinerja budidaya superintensif udang vaname

Table 1. Performance of superintensive culture of shrimp vannamei

\begin{tabular}{|c|c|c|c|c|c|}
\hline & \multicolumn{5}{|c|}{ Padat penebaran (Stocking densities) (ind $/ \mathrm{m}^{2}$ ) } \\
\hline & $500 *)$ & $600 *)$ & 750 & 1000 & 1250 \\
\hline Bobot akhir (Final weight) (g/ind) & & & 15.55 & 16.30 & 15.48 \\
\hline Sintasan (Survival rate) $(\%)$ & 85.6 & 92.4 & 87.3 & 82.9 & 79.1 \\
\hline Pertambahan bo bot harian (Average Daily Gain) (g/day) & 1.14 & 1.14 & 0.19 & 0.21 & 0.20 \\
\hline Produksi (Production) (kg/pond) & 6,376 & 8,407 & 7,862 & 10,699 & 12,163 \\
\hline Produktivitas (Productivity) $\left(\mathrm{kg} / \mathrm{m}^{2}\right)$ & 6.3 & 8.4 & 7.9 & 10.7 & 12.2 \\
\hline Produktivitas (Productivity) $\left(\mathrm{kg} / \mathrm{m}^{3}\right)$ & 3.64 & 4.80 & 4.37 & 5.94 & 6.76 \\
\hline Rasio konversi pakan (Feed conversion ratio) & 1.52 & 1.39 & 1.40 & 1.36 & 1.55 \\
\hline Kebutuhan listrik (Electrical used) (kw/kg shrimp produced) & $2.82 * *)$ & $\left.2.37^{* *}\right)$ & 3.2 & 2.5 & 2.4 \\
\hline Kebutuhan air (Water used) ( $\mathrm{m}^{3} / \mathrm{kg}$ shrimp produced ) & $\left.2.73^{* *}\right)$ & $\left.2.12^{* *}\right)$ & 2.24 & 1.66 & 1.60 \\
\hline Produktivitas kincir (Paddle wheel productivity) (kg/HP) & $\left.425^{* *}\right)$ & $594^{* *}$ & 562 & 669 & 640 \\
\hline Biaya (Cost) (Rp/kg shrimp produced) & 34,032 & 29,650 & 33,730 & 28,614 & 31,598 \\
\hline Laba operasional (Operational profit) (Rp 000/pond/yr) & 186.16 & 308.78 & 219.70 & 312.51 & 244.35 \\
\hline
\end{tabular}

Keterangan (Remark): *) Sumber (Source): Tahe et al. (2014);

**) Diolah dari data yang ada (Processed from the existing data) 
Panen parsial pertama dilakukan pada DOC-70 dengan memanen sebanyak 20-30\%total biomassa di tambak, berkisar 2.271-4.109 kg dengan ukuran 104108 ekor/kg udang. Panen parsial kedua dilakukan pada DOC-90 sebanyak 1.585-3.604 kg dengan ukuran 7184 ekor/kg udang, sedangkan panen akhir dilakukan pada DOC-105 sebanyak 4.006-4.863 kg dengan ukuran 62-69 ekor/kg udang.

Keragaman udang pada saat panen parsial pertama, kedua atau panen akhir memperlihatkan nilai keragaman relatif sama untuk semua petak. Nilai ko efisien variasi dari ketiga tahap panen antara 12,78$22,38 \%$ namun ada indikasi bahwa nilai koefisien variasi semakin kecil pada panen total antara 12,78 $17,74 \% \mathrm{Hal}$ ini mengindikasikan bahwa lebih dari $83 \%$ ukuran udang yang dipanen memiliki bobot yang relatif seragam. Suwoyo et al. (2014) mendapatkan nilai koefisien variasi 12,7-14,6\%pada padat penebaran 500 dan 600 ekor $/ \mathrm{m}^{2}$. Tingkat keseragaman ukuran udang saat panen menjadi salah satu indikator kualitas benur.

Parameter penting yang perlu dipertimbangkan dalam panen parsial udang vaname adalah (a) laju pertumbuhan dan sintasan yang akan menentukan jumlah biomassa udang dalam petakan tambak, (b) persentase udang yang akan dipanen, (c) ukuran dan waktu panen parsial, (d) jumlah panen parsial yang akan dilakukan selama budidaya, dan (e) harga udang pada ukuran panen baik panen parsial maupun panen total.

Konsumsi energi utama adalah untuk kebutuhan operasional aerasi. Jumlah kincir maksimal yang digunakan selama penelitian di petak A, B, dan C masing-masing sebanyak 14, 16, dan 19 unit ditambah dengan root blower $5,5 \mathrm{kw}$ yang digunakan untuk tiga petak dengan asumsi penggunaannya sama. Selama periode budidaya, jumlah energi listrik untuk sistem aerasi dan pompa mencapai 24.867-28.894 kw. Kebutuhan listrik untuk menghasilkan satu kilogram udang cenderung menurun dengan meningkatnya padat penebaran yang berkisar antara 2,4-3,2 kw/kg udang dengan biaya listrik antara Rp. 3.145-4.242/kg udang. Hasil ini relatif sama dengan penelitian sebelumnya yaitu antara 2,37-2,82 kw/kg udang pada padat penebaran 500 dan 600 ekor $/ \mathrm{m}^{2}$ (Tabel 1). Semakin tinggi produksi udang, kebutuhan listrik per kg udang semakin rendah. Hasil penelitian Boyd \& Clay (2002) mendapatkan kebutuhan listrik sebesar $4,35 \mathrm{kw} / \mathrm{kg}$ udang pada tingkat produksi $13.600 \mathrm{~kg} / \mathrm{ha}$. Budidaya dengan sistem resirkulasi tertutup membutuhkan listrik yang lebih besar yaitu 15,4 kw/kg udang pada padat penebaran 450 ekor $/ \mathrm{m}^{3}$ (Samocha et al., 2010a). Kebutuhan listrik dalam budidaya udang vaname superintensif didominasi oleh sistem aerasi yaitu berkisar 85,29-89,87\% Kisaran ini hampir sama dengan hasil penelitian di tahun 2013 yaitu 95,75-96,17\% Sementara penggunaan listrik untuk pompa air sekitar 5-15\% mengindikasikan bahwa kebutuhan listrik untuk pompa air dalam sistem produksi superintensif relatif rendah. Penggunaan 1 HP kincir pada budidaya udang vaname diharapkan dapat mendukung biomassa udang antara 550-600 kg/HP (Hopkins et al., 1991). Dalam penelitian ini dihasilkan $562-669 \mathrm{~kg} / \mathrm{HP}$ dengan nilai rataan $623 \pm 55 \mathrm{~kg}$ udang/HP.

Penggunaan air untuk memproduksi udang vaname superintensif masing-masing sebanyak $2,24 \mathrm{~m}^{3} / \mathrm{kg}$ udang (petak A) dan 1,66 m³/kg udang (petak B) dan $1,60 \mathrm{~m}^{3} / \mathrm{kg}$ udang di petak C (Tabel 1). Kebutuhan air di petak C lebih efisien dibandingkan petak A karena tingkat produktivitas petak $\mathrm{C}$ lebih tinggi dibandingkan petak $A$ dan $B$. Tingginya kebutuhan air dalam sistem budidaya ini dikarenakan pembuangan sludge dilakukan setiap hari dengan frekuensi tiga kali sehari. Boyd \& Clay (2002), mendapatkan kebutuhan air sebanyak $2,26 \mathrm{~m}^{3} / \mathrm{kg}$ udang pada tingkat produksi $13.600 \mathrm{~kg} / \mathrm{ha}$. Metode budidaya superintensif dengan sistem resirkulasi tanpa ganti air, membutuhkan volume air sebanyak $110 \pm 12 \mathrm{~L} / \mathrm{kg}$ udang pada padat penebaran 450 ekor $/ \mathrm{m}^{3}$ dengan produktivitas udang $9,53 \pm 0,17 \mathrm{~kg} / \mathrm{m}^{3}$ dan $149 \pm 6 \mathrm{~L} / \mathrm{kg}$ udang padat penebaran 530 ekor $/ \mathrm{m}^{3}$ dengan produktivitas $8,60 \pm 0,56 \mathrm{~kg} / \mathrm{m}^{3}$ atau $4,64 \pm 0,28 \mathrm{~kg} / \mathrm{m}^{2}$ (Samocha et al., 2010a); 157,6 \pm 7,9 L/kg udang pada penebaran 500 ekor $/ \mathrm{m}^{3}$ dan produktivitas $9,58 \pm 0,18 \mathrm{~kg} / \mathrm{m}^{3}$; dan $158,1 \pm 8,5 \mathrm{~L} / \mathrm{kg}$ udang pada padat penebaran $390 \mathrm{ekor} /$ $\mathrm{m}^{3}$ dan produktivitas $8,36 \pm 0,32 \mathrm{~kg} / \mathrm{m}^{3}$ (Samocha et al., 2013b). Venero et al. (2009), melaporkan penggunaan air sebanyak $130 \mathrm{~L} / \mathrm{kg}$ udang dengan tingkat produksi $6,92 \mathrm{~kg} / \mathrm{m}^{2}$ pada padat penebaran 581 ekor $/ \mathrm{m}^{2}$. Kebutuhan air kurang dari satu meter kubik umumnya terjadi pada sistem budidaya tertutup dengan menerapkan zero water exchange. Jadi perbedaan kebutuhan air yang digunakan disebabkan oleh sistem budidaya dan manajemen air yang diaplikasikan serta skala wadah budidaya yang digunakan.

\section{Kualitas Air Tambak Percobaan}

Selama perio de budidaya, temperatur air bervariasi antara $25,3-31,6^{\circ} \mathrm{C}$ dengan nilai rataan dari ketiga tambak $28,08 \pm 1,08^{\circ} \mathrm{C}$. Udang vaname akan tumbuh baik pada suhu air $28-32^{\circ} \mathrm{C}$ (Krummenauer et al., 2011). Sementara oksigen terlarut berkisar antara 0,5-10,6 ppm dengan nilai rataan dari ketiga tambak sebesar $5,48 \pm 1,25 \mathrm{ppm}$. Oksigen terlarut menjadi salah satu peubah kualitas air yang sangat penting untuk menopang kehidupan udang. Oleh karena itu sistem aerasi merupakan suatu hal yang terpenting dalam 
sistem produksi udang sebagai pemasok oksigen terlarut dalam air tambak untuk kehidupan udang dan mendukung proses dekomposisi aerobik bahan organik dan nitrifikasi oleh bakteri. Aerasi juga menghasilkan arus air dan proses pengadukan massa air tambak sehingga dapat mempertahankan bakteri dan mikroorganisme lainnya dalam kondisi suspensi.

Salinitas air tambak berkisar dari 22,1-22,7 ppt di awal penebaran meningkat menjadi 28,7-28,9 ppt di akhir pemeliharaan, namun variasi ini tidak mempengaruhi terhadap pertumbuhan udang. Nilai rataan salinitas dari ketiga petak tambak adalah $25,4 \pm 2,3$ ppt, artinya salinitas ketiga petak tambak relatif sama fluktuasinya.

Upaya mempertahankan $\mathrm{pH}$ air harian dalam budidaya udang vaname superintensif menjadi suatu keharusan agar stabilitas kualitas air dapat terjaga dengan baik. Jika pH air dapat dijaga pada kisaran variasi < 1 maka peubah kualitas air lainnya tidak mengalami goncangan dan berada pada kondisi yang layak bagi kehidupan udang. Selama pemeliharaan udang, $\mathrm{pH}$ air tambak berkisar 6,5-8,4 dengan nilai rataan harian dari ketiga petak tambak adalah 7,5 0,2.

Pada budidaya udang superintensif, terjadi eskresi TAN yang tinggi, karena udang banyak menggunakan protein sebagai sumber energi. Jika dijumlahkan $\mathrm{N}$ yang diekskresikan + $\mathrm{N}$ dalam feses dan sisa pakan, maka nilainya sekitar $75 \%$ atau hanya sekitar $25 \% \mathrm{~N}$ yang diretensi dalam tubuh hewan budidaya. Rachmansyah et al. (2014) memperoleh nilai retensi $\mathrm{N}$ pakan pada budidaya udang vaname dengan padat penebaran 500-600 ekor $/ \mathrm{m}^{2}$ berkisar 38,71-42,35\% artinya lebih dari $60 \% \mathrm{~N}$ pakan akan terbuang ke lingkungan. $\mathrm{N}$ organik dalam sisa pakan dan feses selanjutnya akan membentuk TAN setelah melewati proses penguraian oleh bakteri. TAN ini bersifat toksik jika terakumulasi sampai kadar tertentu, sehingga pada akuakultur intensif harus sering dilakukan pergantian air untuk membuang TAN tersebut. Pakan yang digunakan berkadar protein 3540\%sehingga cukup memberikan kontribusi yang nyata terhadap konsentrasi TAN yang mencapai kisaran 0,0657-18,9200 ppm. Kemudian, proses nitrifikasi menjadi faktor utama dan bakteri nitrifikasi secara cepat mengkonversi amonia nitrogen menjadi nitrat. Konsentrasi amonia di atas 4 atau 5 ppm akan menjadi racun bagi udang (Boyd and Clay, 2002). Dalam penelitian ini, konsentrasi nitrit antara 0,006240,3000 ppm dan nitrat antara 0,0794-55,3000 ppm, tetapi nitrat tidak bersifat racun bagi udang pada konsentrasi di bawah 50 ppm (Boyd \& Clay, 2002).

\section{Analisis Biaya Budidaya Udang Vaname Superintensif}

Berdasarkan akuainput yang digunakan dalam proses budidaya udang vaname superintensif diperoleh informasi bahwa biaya produksi udang vaname yang paling rendah adalah pada padat penebaran 1.000 ekor/m² sebesar Rp.30.526/kg udang (Tabel 2). Komponen biaya tertinggi dalam proses produksi udang vaname adalah pakan berkisar Rp. 19.108$21.778 / \mathrm{kg}$ yang berkontribusi antara $60,10-64,80 \%$ diikuti oleh kebutuhan benur $(13,10-13,80 \%$ dan listrik $(9,56-13,10 \%$. Laba operasional tertinggi dalam dua kali musim tanam per tahun, diperoleh pada petak $\mathrm{C}$ (1.250 ekor $/ \mathrm{m}^{2}$ ) sebesar Rp. 641.893.370,- diikuti oleh petak B $\left(1.000\right.$ ekor $\left./ \mathrm{m}^{2}\right)$ dan A $\left(750\right.$ ekor $\left./ \mathrm{m}^{2}\right)$ masingmasing Rp. 630.687.094,-dan Rp. 428.624.761,--ketiga padat penebaran masih menghasilkan nilai $\mathrm{R} / \mathrm{C}$ rasio $>1$ yang berarti usaha tersebut layak secara ekonomi (Tabel 2). Padat penebaran 500 dan $600 \mathrm{ekor} / \mathrm{m}^{2}$ menghasilkan laba operasional per tahun masingmasing Rp. 221.256 .579 dan Rp. 290.882.382,- dan imbangan penerimaan biaya (R/C) masing-masing 1,45 dan 1,61 (Tahe et al., 2014).

Aplikasi padat penebaran 1.000 ekor $/ \mathrm{m}^{2}$ menghasilkan jangka waktu pengembalian modal 0,91 tahun dan nilai BEP sebesar Rp. 391.126.938, lebih rendah dibandingkan kedua perlakuan lainnya. Demikian halnya nilai R/C sebesar 1,52 lebih tinggi dari perlakuan lainnya. Peningkatan padat penebaran tidak diikuti secara linier baik oleh produksi maupun laba operasional. Hal ini mengindikasikan bahwa padat penebaran $1.000 \mathrm{ekor} / \mathrm{m}^{2}$ menghasilkan tingkat kelayakan usaha paling tinggi dan dapat dijadikan acuan padat penebaran dalam operasional budidaya udang vaname superintensif.

\section{KESIMPULAN DAN SARAN}

Budidaya udang vaname dengan padat penebaran tinggi secara teknis dapat dilakukan, secara ekonomi menguntungkan, dan dapat diterima oleh masyarakat pembudidaya. Berdasarkan jangka waktu pengembalian modal, $\mathrm{R} / \mathrm{C}$ rasio, dan titik impas, maka padat penebaran 1.000 ekor $/ \mathrm{m}^{2}$ menghasilkan performa budidaya terbaik dan dinilai paling layak untuk diaplikasikan.

\section{UCAPAN TERIMA KASIH}

Ucapan terima kasih disampaikan kepada BPPBAP Maros yang telah mendanai penelitian ini melalui anggaran APBN 2014 Balai Penelitian dan Pengembangan Budidaya Air Payau. Ucapan terima 
Tabel 2. Analisa biaya budidaya udang vaname superintensif dengan dua kali penebaran per tahun Table 2. Cost analysis of vannamei shrimp farming superintensif with stocking twice per year

\begin{tabular}{|c|c|c|c|c|c|c|}
\hline \multirow{3}{*}{ Peubah (Variables) } & \multicolumn{6}{|c|}{ Padat penebaran (Stocking densities) (ind//m²) } \\
\hline & \multicolumn{2}{|c|}{750} & \multicolumn{2}{|c|}{1} & \multicolumn{2}{|l|}{1.25} \\
\hline & $\begin{array}{c}\text { Nilai } \\
\text { Value (Rp) }\end{array}$ & $\%$ & $\begin{array}{c}\text { Nilai } \\
\text { Value (Rp) }\end{array}$ & $\%$ & $\begin{array}{c}\text { Nilai } \\
\text { Value (Rp) }\end{array}$ & $\%$ \\
\hline Benur (Seed) & 4,293 & 13.10 & 4,206 & 13.8 & 4,625 & 13.80 \\
\hline Pakan (Feed) & 19,67 & 60.10 & 19,108 & 62.60 & 21,778 & 64.80 \\
\hline Listrik (Electrical) & 4,276 & 13.10 & 3,324 & 10.9 & 3,212 & 9.56 \\
\hline Bahan aditif (Additif materials) & 834 & 2.55 & 884 & 2.90 & 1,035 & 3.08 \\
\hline Tenaga kerja (Labour) & 1,526 & 4.66 & 1,122 & 3.68 & 987 & 2.94 \\
\hline Lain-lain (M iscellaneous) & 2,141 & 6.54 & 1,881 & 6.16 & 1,977 & 5.88 \\
\hline $\begin{array}{l}\text { Biaya per kg udang } \\
\text { Cost production (Rp./kg shrimp produced) }\end{array}$ & 32,741 & 100 & 30,526 & 100 & 33,613 & 100 \\
\hline Produksi (Production) (kg/yr) & \multicolumn{2}{|c|}{15,724} & \multicolumn{2}{|c|}{21,398} & \multicolumn{2}{|c|}{24,326} \\
\hline $\begin{array}{l}\text { Biaya operasional } \\
\text { Operational cost (Rp/yr) } 2 \text { cycle }\end{array}$ & \multicolumn{2}{|c|}{$706,950,572$} & \multicolumn{2}{|c|}{$845,328,239$} & \multicolumn{2}{|c|}{$1,009,801,963$} \\
\hline Total penerimaan (Total revenue) (Rp/yr) & \multicolumn{2}{|c|}{$943,440,000$} & \multicolumn{2}{|c|}{$1,283,880,000$} & \multicolumn{2}{|c|}{$1,459,560,000$} \\
\hline Laba operasional (Operational profit) (Rp/yr) & \multicolumn{2}{|c|}{$428,624,761$} & \multicolumn{2}{|c|}{$630,687,094$} & \multicolumn{2}{|c|}{$641,893,370$} \\
\hline $\begin{array}{l}\text { Jangka waktu pengembalian } \\
\text { Pay back periode (yr) }\end{array}$ & \multicolumn{2}{|c|}{1.10} & \multicolumn{2}{|c|}{0.91} & \multicolumn{2}{|c|}{0.92} \\
\hline $\mathrm{R} / \mathrm{C}$ rasio & \multicolumn{2}{|l|}{1.33} & \multicolumn{2}{|l|}{1.52} & \multicolumn{2}{|c|}{1.44} \\
\hline Titik impas (Break even point) (Rp) & \multicolumn{2}{|c|}{$422,906,410$} & \multicolumn{2}{|c|}{$391,126,938$} & \multicolumn{2}{|c|}{$436,884,162$} \\
\hline
\end{tabular}

Catatan (Note): Asumsi harga jual udang (Assuming the sale price of shrimp)= Rp. 60.000/kg

kasih dan penghargaan yang tinggi disampaikan kepada tim peneliti, teknisi litkayasa dan analis serta pengelola anggaran yang telah mendukung jalannya penelitian ini.

\section{DAFTAR ACUAN}

Atjo, H. (2013). Keberlanjutan budidaya udang vaname supra-intensif Indonesia. Dipresentasikan pada Workshop Keberlanjutan Budidaya Vaname SupraIntensif. Makassar, 23-24 Oktober 2013, 42 hlm.

Balakrishnan, G., Peyail, S., Ramachandran, K., Theivasigamani, A., Savji, K.A., Chokkaiah, M., \& Nataraj, P. (2011). Growth of cultured white leg shrimp Litopenaus vannamei (Boone 1931) in different stocking density. Advances in Applied Science Research, 2(3), 107-113.

Boyd, C.E. \& Clay, J.W. (2002). Evaluation of Belize Aquaculture, Ltd: A Superintensive Shrimp Aquaculture Systems. Report prepared under the World Bank, NACA, WWF and FAO Consortium Program on Shrimp Farming and the Environment. Work in Progress for Public Discussion. Published by the Consortium, $17 \mathrm{pp}$.

Hopkins, J.S., Stokes, A.D., Browdy, C.L., \& Sandifer, P.A. (1991). The relationship between feeding rate, paddlewheel aeration rate and expected dawn dissolved oxygen in intensive shrimp ponds. Aquaculural Engineering, 10, 281-290.

Krishna, P.V., Prakash, B.K., Kumar, V.H., \& Prabhavathi, K. (2015). Growth, survival and production of Pacific white shrimp Litopenaeus vannamei at different stocking densities under semiintensive culture system in Andhra Pradesh. International Journal of Advanced Research, 3(9), 446-452.

Krummenauer, D., Peixoto, S., Cavalli, R.O., Poersch, L.H., \& Wasielesky Jr, W. (2011). Superintensive culture of white shrimp, Litopenaeus vannamei, in a biofloc technology systems in Southern Brazil at different stocking densities. Journal of theW orld Aquaculture Society, 42(5), 726-733.

Lawrence, A.L. (2010). Super-intensive raceway shrimp production. The road to sustainability. Tahiti Aquaculture 2010. Papeete, Tahiti, December 07, 2010, 15 pp.

Moos, S.M., Otosi, C.A., \& Leung, P. (2005). Bigger shrimp: Optimizing strategies for growing larger L. vanamei. Global Aquaculture Advocate, October 2005, 68-69.

Otoshi, C.A., Naguwa, S.S., Falesch, F.C., \& Moss, S.M. (2007). Shrimp behaviour may affect culture 
performance at superintensive stocking densities. Global Aquaculture Advocate, March/April 2007, p. 67-69.

Rachmansyah, Makmur, \& Undu, M.C. (2014). Estimasi beban limbah nutrien pakan dan daya dukung kawasan pesisir untuk tambak udang vaname superintensif. Jurnal Riset Akuakultur, 9(3), 439-448.

Samocha, T., Correia, E.S., W ilkenfeld, J., Morris, T.C., $\&$ Wei, L. (2010a). High-density production of the Pacific White shrimp, Litopenaeus vannamei, in recycle culture water under zero-exchange conditions using settling tanks, foam fractionators and dissolved oxygen monitoring systems as managemen tools. Aquaculture 2010 San Diego, March 1-5, 2010.

Samocha, T.M., Wilkenfeld, J.S., Morris, T.C., Correia, E.S., \& Hanson, T. (2010b). Intensive raceways without water exchange analyzed for white shrimp culture. Global Aquaculture, July/August 2010, p. 2224.

Samocha, T.M., Schveitzer, R., Krummenauer, D., \& Morris, T.C. (2012). Recent advance in super-intensive, zero-exchange shrimp raceway systems. Global Aquaculture November/December 2012, p. 70-71.

Samocha, T.M., Braga, A., Magalhaes, V., Advent, B., $\&$ Morris, T.C. (2013a). Ongoing studies advance intensive shrimp culture in zero-exchange biofloc raceway. Global Aquaculture March/April 2013, p. 38-40.

Samocha, T., Morris, T.C., Braga, A., Magalhaes, V., Schveizer, R., Krummenauer, D., Correia, E.S., Kim, J.S., Austin, J.J., Mishra, J.K., Burger, J., Advent, B., \& Hanson T. (2013b). Shrimp production in greenhouse-enclosed superintensive biofloc systems at the Texac A\&M AgriLife Research Mariculture Lab:2003-2012. Aquaculture 2013 Nashville, Tennessee, USA. February 21-25, 2013, 37 pp.

Suwoyo, H.S., Makmur, \& Tahe, S. (2014). Keragaman hasil panen udang vaname (Lito penaeus vannamei) di tambak superintensif. Prosiding Seminar Nasional Tahunan XI Hasil Penelitian Perikanan dan Kelautan, UGM, 30 Agustus 2014, RB-18, 289-297.

Tahe, S., Mangampa, M., \& Makmur. (2014). Kinerja budidaya udang vaname (Litopenaeus vannamei) pola super intensif dan analsis biaya. Prosiding Forum Inovasi Teknologi Akuakultur 2014, p. 23-30.

Taw, N., Fuat, H., Tarigan, N., \& Sidabutar, K. (2006). Partial harvest with BFT: Promising for Pacific White Shrimp. Global Aquaculture Advocate, September/October, p. 84-86.

Venero, J.A., McAbee, B., Lawson, A., Lewis, B.L., Leffler, J.W., \& Browdy, C.L. (2009). GreenhouseEnclosed superintensive shrimp production: Alternative to traditional ponds in U.S. Global Aquaculture Advocate, January/February, 2009, p. 61-64.

Wasielesky, W., Froes, C., Foes, G., Krummenauer, D., Lara, G., \& Poersh, L. (2013). Nursery of Litopenaeus vannamei reared in a biofloc system: The effect of stocking densities and compensatory growth. Journal of Shellfish Research, 32(3), 799-806.

Yu., R. \& Leung, P. (2006). Optimal partial harvesting schedule for aquaculture operations. Marine Resources Economics, 21, 301-315.

Yu, R., Leung, P., Kam, L.E., \& Bienfang, P. (2010). A Decision Support System for Scheduling Partial Harvesting in Aquaculture. IGI. Global, p. 406-509. 